\title{
Analysis of large-cell lymphomas using monoclonal and heterologous antibodies
}

\author{
P VAN DER VALK, G VAN DEN BESSELAAR-DINGJAN, MR DAHA*, CJLM MEIJER $\dagger$
}

From the Departments of Pathology and *Internal Medicine, University Medical Centre, Leiden, and the †Department of Pathology, Stichting Samenwerking Delftse Ziekenhuizen, Reynier de Graefweg 7, Delft, The Netherlands

SUMMARY Fifteen cases of large-cell lymphoma, diagnosed as centroblastic (5), B-immunoblastic (5) or true histiocytic (5). lymphoma and one case of malignant histiocytosis were studied with monoclonal antibodies. Each diagnosis was based on morphological as well as marker studies. A panel of monoclonal and heterologous antibodies against $\mathrm{T}$ lymphocyte differentiation antigens (Leul, Leu2a, Leu3a, OKT4, OKT8, TA1), B lymphocyte subsets (BA1, BA2, HLA-DR, $\alpha \mathrm{C} 3 \mathrm{~b}$ receptor antiserum, surface immunoglobulins), the common acute lymphoblastic leukaemia antigen (CALLA), monocytes/ macrophages (OKM1, anti-human monocyte 1, TA1, Macl, HLA-DR, anti-C3b receptor), myeloid cells (VIM-D5, elastase, OKM1) and the cells of the Langerhans cell/interdigitating reticulum cell series (OKT6, NA1/34).The results show. a specific staining pattern for true histiocytic lymphoma (histiocytic sarcoma). Centroblastic and B-immunoblastic lymphomas showed gradual differences with mostly strong staining for HLA-DR and weak with anti $\mathrm{C} 3 \mathrm{~b}$ receptor for B-immunoblastic lymphomas in contrast to centroblastic lymphomas. Staining with BA1 and BA2 indicated immunological heterogeneity in these lymphomas. The number of admixed cells was usually low with few B cells and a shift in the ratio helper/inducer to suppressor/cytotoxic $\mathrm{T}$ cells in favour of the suppressor/cytotoxic subset.

In studying the non-Hodgkin's lymphomas identification of the nature of neoplastic cells is usually based on immunological techniques, cytochemistry, and electron microscopy, using classical markers; for example, surface membrane and/or intracytoplasmic immunoglobulins, rosette formation with sheep erythrocytes, staining with heterologous $\mathrm{T}$ cell antisera, presence of $\mathrm{Fc}$ gamma and complement (C3) receptors, acid phosphatase and/or alpha-naphthyl acetate esterase activity, etc. The recent development of monoclonal antibodies directed against defined antigens present on subsets of lymphoid and histiocytic cells has created new possibilities to differentiate between the various types of large-cell lymphomas. ${ }^{\prime}$ In the present study 15 cases of large-cell lymphomas, classified as centroblastic (5), B-immunoblastic lymphoma (5) or histiocytic sarcoma (5) with conventional immunological markers, cytochemistry and electron microscopy and one case of malignant histiocytosis were investigated with a panel of monoclonal antibodies directed against antigens present on subsets of lymphoid, histiocytic and/or myeloid cells to find out whether the mentioned subtypes of large-cell lymphomas form immunologically heterogeneous groups. Moreover, the

Accepted for publication 2 August 1982 monoclonal antibodies were investigated for their $\frac{0}{3}$ diagnostic value in the differentiation of large-cell lymphomas.

\section{Material and Methods}

TISSUE PROCESSING

Each tissue specimen was cut into four pieces. One was fixed in buffered formalin (routine histology), one was 0 fixed in a sublimate-formaldehyde mixture (immunohistochemistry), ${ }^{2}$ one was fixed in a fixative $\frac{7}{0}$ according to Burkhardt (plastic embedding), ${ }^{3}$ and one piece was snap-frozen in liquid nitrogen. For electron $N$ microscopy, eight small blocks of tissue had been cut from $N$ one of the four pieces before fixation or freezing. These $\mathrm{N}$ blocks were fixed according to McDowell and Trump. ${ }^{4} \mathrm{G}$

\section{Immunohistochemistry}

Immunohistochemical investigation was carried out on paraffin-embedded sections $(4 \mu \mathrm{m})$. It included staining with rabbit antibodies by an indirect immunoperoxidase $\bar{O}$ technique for kappa and lambda light chains, alpha, $\underset{\mathbb{D}}{\mathbb{D}}$ gamma and mu heavy chains, lysozyme (all obtained $\frac{\mathcal{P}}{\Phi}$ from Dakopatts, Denmark), alpha-1-antitrypsin and $\varrho$ alpha-1-antichymotrypsin (Behringwerke, Amsterdam). 
As a second step a goat-antirabbit IgG tagged with horseradish peroxidase, prepared in our laboratory, was used. The specificity of these antibodies and the controls of the staining procedure have been described in detail before. $^{5}$ The elastase antiserum used was a rabbitantihuman antibody, prepared by Dr JA Kramps from granulocytes. It was tested on a variety of normal and neoplastic tissues and cell suspensions and proved virtually specific in staining myeloid elastase ${ }^{6}$ (Table 1 ).

\section{Immunofluorescence}

These studies were performed on cryostat sections $(4 \mu \mathrm{m})$ using an indirect immunofluorescence technique with the

Table 1 Antibodies and their specificity

\begin{tabular}{|c|c|c|}
\hline Antibody & $\begin{array}{c}\text { Monoclonal } \\
(M) \\
\text { Heterologous } \\
(H)\end{array}$ & Specificity. \\
\hline Leu 1 & M & $\begin{array}{l}95 \% \text { human thymocytes. } \geqslant 95 \% \\
\text { peripheral T lymphocytes. some } \\
\text { sIg + B-CLL cells. no normal } \\
\text { B lymphocytes }{ }^{16}\end{array}$ \\
\hline Leu2ạ & M & $\begin{array}{l}\text { suppressor/cytotoxic } \\
\text { T subset }{ }^{17}\end{array}$ \\
\hline Leu3a & M & helper/inducer T subset ${ }^{18}$ \\
\hline OKT4 & M & helper/inducer T subset ${ }^{19}$ \\
\hline OKT8 & M & $\begin{array}{l}\text { suppressor/cytotoxic } \\
\text { T subset }{ }^{20}\end{array}$ \\
\hline TAl & M & $\begin{array}{l}100 \% \text { peripheral blood } \\
\text { T lymphocytes. } 70 \% \\
\text { thymocytes, } \geqslant 95 \% \text { peripheral } \\
\text { blood monocytes } 21\end{array}$ \\
\hline BAl & $\mathbf{M}$ & $\begin{array}{l}\text { peripheral blood B-lymphocytes. } \\
\text { pre-B-ALL and B-CLL cells. } \\
\text { granulocytes }^{22}\end{array}$ \\
\hline BA2 & M & $\begin{array}{l}<1 \% \text { peripheral blood } \\
\text { lymphocytes. lymphohemopoietic } \\
\text { progenitor cells in bone } \\
\text { marrow, non T-non B-ALL } \\
\text { cells }\end{array}$ \\
\hline HLA-DR & M & $\begin{array}{l}\text { B lymphocytes. } \\
\text { monocytes/macrophages, } \\
\text { activated T lymphocytes }\end{array}$ \\
\hline $\begin{array}{l}\text { anti-C3b- } \\
\text { receptor }\end{array}$ & $\mathrm{H}$ & $\begin{array}{l}\text { cells having a } C 3 \text { b receptor- } \\
\text { that is, macrophages, dendritic } \\
\text { reticulum cells, a subset of } \\
\text { B lymphocytes }{ }^{39}\end{array}$ \\
\hline OKMI & M & $\begin{array}{l}\text { peripheral blood monocytes. } \\
\text { granulocytes, acute } \\
\text { myelomonocytic leukemia cells }{ }^{25}\end{array}$ \\
\hline Macl & M & $\begin{array}{l}\text { macrophages, granulocytes. } \\
\text { blood monocytes }{ }^{26}\end{array}$ \\
\hline $\begin{array}{l}\text { anti human } \\
\text { monocyte } 1\end{array}$ & M & $\begin{array}{l}\text { peripheral blood monocytes } \\
<25 \% \text { of granulocytes. } 25 \% \text { of } \\
\text { platelets } 2 f\end{array}$ \\
\hline OKT6 & $\mathbf{M}$ & $\begin{array}{l}70 \% \text { thymocytes, epidermal } \\
\text { Langerhans cells }\end{array}$ \\
\hline $\mathrm{NAl} / 34$ & $\mathbf{M}$ & $\begin{array}{l}\text { cortical thymocytes, epidermal } \\
\text { Langerhans cells } \\
\text { intedigitating reticulum } \\
\text { cells of the lymph node }\end{array}$ \\
\hline CALLA & $\mathbf{H}$ & cells of non T-non B-ALL ${ }^{31}$ \\
\hline VIM-D5 & $\mathbf{M}$ & $\begin{array}{l}\text { granulocytes, myelocytes, } \\
\text { myeloblasts, monoblasts }{ }^{3 ;}\end{array}$ \\
\hline $\begin{array}{l}\text { anti- } \\
\text { elastase }\end{array}$ & $\mathbf{H}$ & $\begin{array}{l}\text { granulocytes, myelocytes. } \\
\text { myeloblasts }^{6}\end{array}$ \\
\hline sIg & $\mathrm{H}$ & $\begin{array}{l}\text { cells carrying immunoglobulins } \\
\text { in their surface-that is } \\
\text { mainly B lymphocytes }\end{array}$ \\
\hline
\end{tabular}

same antisera as mentioned above. In addition a rabbit antibody against delta heavy chain was used. This antibody was obtained from the Central Laboratory of the Blood Transfusion Service (Amsterdam), as was the second step, a horse-antirabbit IgG, tagged with FITC.

\section{Rosette Assays}

These were used to test for the presence of receptors for the activated third component of complement (C3 receptors) and the Fc portion of IgG (Fc gamma receptors). Ox erythrocytes coated with rabbit IgM antibody and complement, or with a rabbit IgG antibody were used, ${ }^{7} 8$ respectively. IgM coated or uncoated ox erythrocytes were used as controls.

\section{Cytochemistry}

Cytochemical investigation was done on cryostat sections $(8 \mu \mathrm{m})$ and included staining for acid phosphatase and alpha-naphthyl acetate esterase, ${ }^{9}$ alkaline phosphatase ${ }^{10}$ and 5-nucleotidase and adenosine triphosphatase. ${ }^{11}$

\section{Electron Microscopy}

Small tissue blocks were postfixed in $1.5 \%$ osmium tetroxide and dehydrated in a graded series of alcohol solutions. The specimens were then embedded in Epon 812. A semithin section was used to select a representative area, the specimen was trimmed, cut ultrathin and stained with uranyl acetate and lead citrate.

DIAGNOSIS OF THE DIFFERENT SUBTYPES OF LARGE-

\section{CELL LYMPHOMA}

The diagnosis of each subtype of lymphoma was based on the morphological criteria defined by Gerard-Marchant $e t$ $a l^{12}$ and Lennert et $a^{13}$ for the tumours of lymphoid origin and on the criteria of van der Valk et $a l^{514}$ for true histiocytic lymphomas. The diagnosis was supported by the following marker criteria:

Centroblastic lymphomas must have monoclonal surface immunoglobulins (sIg) and moderate to strong C3 receptors as demonstrated with the red-cell overlayer technique but no or weak intracytoplasmic immunoglobulins (cIg).

B-immunoblastic lymphomas had both sIg and clg but no or very weak $\mathrm{C} 3$ receptors.

Histiocytic sarcoma had no sIg or cIg, but showed C3 and Fc gamma receptors, diffuse granular, cytoplasmic acid phosphatase as well as alpha-naphthyl acetate esterase activity. Lysozyme, alpha-1-antitrypsin and/or alpha-1-antichymotrypsin were also demonstrable in the cytoplasm.

The one case of malignant histiocytosis showed the same marker characteristics as the histiocytic sarcomas. Morphological criteria of Byrne and Rappaport were used. ${ }^{15}$ 
Table 2(a) Results of staining with monoclonal antibodies: tumour cells

\begin{tabular}{|c|c|c|c|c|c|c|c|c|c|c|c|c|}
\hline & & $T A I$ & $B A I$ & $B A 2$ & $H L A-D R$ & $x C 3 b$ & $O K M I$ & Macl & aHMI & $N A / / 34$ & $\lg$ & \\
\hline \multirow{6}{*}{$\begin{array}{l}\text { Histiocytic } \\
\text { sarcoma }\end{array}$} & & & & & & & $+k$ & $70 \% \%^{*}$ & & & & No tumour cells stained with: \\
\hline & 1 & $+*$ & $\ldots$ & - & $+*$ & $+*$ & weakly & (weakly) & $+*$ & +4 & - & - Leu 1 \\
\hline & 2 & $70 \% *$ & - & - & $80 \% *$ & $70 \% *$ & $50 \% *$ & $50 \% *$ & $70 \% *$ & few & - & - Leu $2 \mathrm{a} / \mathrm{OKT} 8$ \\
\hline & 3 & $80 \% *$ & $\begin{array}{l}\text { few } \\
\text { (weakly) }\end{array}$ & - & $90 \% *$ & $70 \% *$ & $60 \%$ & $60 \% *$ & $80 \% \%$ & $70 \%$ & & $\begin{array}{l}\text { Leu } 3 \mathrm{a} / \mathrm{OKT} 4 \\
\text { OKT6 }\end{array}$ \\
\hline & 4 & $80 \% *$ & - & & +5 & $70 \% *$ & $50 \% *$ & $50 \%$ & $90 \% *$ & $70 \% *$ & $\ldots$ & - VIM-D5 \\
\hline & 5 & $60-70 \%$ & few* & - & $60 \% *$ & $60 \% *$ & $40 \% *$ & $50 \% *$ & $70 \% *$ & $30 \% *$ & - & $\begin{array}{l}\text { anti-elastase } \\
\text { CALLA }\end{array}$ \\
\hline $\begin{array}{l}\text { Malignant } \\
\text { histiocytosis }\end{array}$ & & & & & & & $+*$ & $+*$ & $+*$ & $+\%$ & - & \\
\hline \multirow{7}{*}{$\begin{array}{l}\text { Centroblastic } \\
\text { lymphoma }\end{array}$} & & & & & & & & & & & & \\
\hline & & & & & + & & & & & & & \\
\hline & 1 & - & - & few & $\begin{array}{l}\text { (weakly) } \\
+\end{array}$ & $50-60 \%$ & - & - & - & - & $\lambda G$ & \\
\hline & 2 & - & $\ldots$ & few & (weakly) & $40-50 \%$ & - & - & ... & - & $\lambda G$ & \\
\hline & 3 & - & - & $\cdots$ & $+\infty$ & $\begin{array}{l}60-70 \% \\
60-70 \%\end{array}$ & *- & - & - & & $\kappa \mathrm{M}$ & \\
\hline & 4 & - & $<10 \%$ & -- & $20 \%$ & (weakly) & $\ldots$ & - & - & - & $\kappa G$ & \\
\hline & 5 & - & $-\ldots$ & $50 \%$ & $25 \%$ & + & -- & - & - & - & $\kappa \mathrm{M}$ & \\
\hline \multirow{6}{*}{$\begin{array}{l}\text { Immunoblastic } \\
\text { lymphoma }\end{array}$} & & & $40-50 \%$ & & & & & & & & & \\
\hline & 1 & - & (weakly) & - & + & few & - & -- & - & & $\lambda G^{*}$ & \\
\hline & 2 & - & -- & - & ++ & few & $\cdots$ & - & - & - & $\kappa \mathrm{M}^{*}$ & \\
\hline & 3 & - & $<10 \%$ & (weakly) & ++ & $\ldots$ & - & - & - & - & $\lambda M$ & \\
\hline & 4 & - & few & $80 \%$ & few & few & - & - & - & -.- & $\kappa M^{*}$ & \\
\hline & 5 & - & $70-80 \%$ & - & ++ & - & - & $\cdots$ & - & $\cdots$ & $\lambda \mathrm{M}^{*}$ & \\
\hline
\end{tabular}

*Intracytoplasmic

Percentage estimated semiquantitatively from the total number of tumourcells

Monoclonal antibodies described in Table 1.

Ig = class of immunoglobulin.

Table 2(b) Results of staining with monoclonal antibodies: admixed cells

\begin{tabular}{|c|c|c|c|c|c|c|c|c|}
\hline \multicolumn{6}{|l|}{ (Tlymphocytes) } & \multirow{2}{*}{$\begin{array}{l}\text { (BLymphocyte) } \\
H L A-D R, B A I \\
\left.\kappa \lambda_{i}\right) \operatorname{rr} 3 b\end{array}$} & \multirow{2}{*}{$\begin{array}{l}\text { (Macrophages) } \\
\text { aHMI,OKMI.TAI } \\
x(3 b, H L A-D R\end{array}$} & \multirow{2}{*}{$\begin{array}{l}\text { (Myeloidcells) } \\
\text { VIM-D5.OKMI } \\
\text { anti-elastase }\end{array}$} \\
\hline & & $\begin{array}{l}\text { Leul, TAI } \\
\text { Pan-T }\end{array}$ & $\begin{array}{l}\text { Leu3a, OKT4 } \\
\text { helper } \\
\text { inducer }\end{array}$ & $\begin{array}{l}\text { Leu2a. OKT8 } \\
\text { suppressor } \\
\text { cytotoxic }\end{array}$ & $\begin{array}{l}\text { Estimated } \\
\text { ratio } H: S\end{array}$ & & & \\
\hline $\begin{array}{l}\text { Histiocytic } \\
\text { sarcomas }\end{array}$ & $\begin{array}{l}1 \\
2 \\
3 \\
4 \\
5\end{array}$ & $\begin{array}{l}25 \% \\
<5 \% \\
10-20 \% \\
<5 \% \\
25 \%\end{array}$ & $\begin{array}{l}10-15 \% \\
<5 \% \\
10-15 \% \\
<5 \% \\
10 \%\end{array}$ & $\begin{array}{l}10-15 \% \\
<5 \% \\
5-10 \% \\
<5 \% \\
15-20 \%\end{array}$ & $\begin{array}{l}1: 1 \\
1: 1 \\
1-2: 1 \\
1: 1 \\
1-2: 1\end{array}$ & $\begin{array}{l}20-30 \% \\
\text { few } \\
\text { few } \\
\text { few } \\
10-15 \%\end{array}$ & & few \\
\hline $\begin{array}{l}\text { Centroblastic } \\
\text { lymphomas }\end{array}$ & $\begin{array}{l}1 \\
2 \\
3 \\
4 \\
5\end{array}$ & $\begin{array}{l}\text { few } \\
25 \% \\
\text { few } \\
5-10 \% \\
5-10 \%\end{array}$ & $\begin{array}{l}\text { few } \\
15-20 \% \\
\text { few } \\
5 \% \\
5-10 \%\end{array}$ & $\begin{array}{l}\text { few } \\
1()-15 \% \\
\text { few } \\
5-10 \% \\
5 \%\end{array}$ & $\begin{array}{l}1: 1 \\
1-2: 1 \\
1: 1 \\
1: 1-1 \\
1-2: 1\end{array}$ & $\begin{array}{l}\text { few } \\
15-20 \% \\
5 \% \\
10 \% \\
20 \%\end{array}$ & $\begin{array}{l}5 \% \\
5-10 \% \\
5-10 \% \\
5 \% \\
20 \%\end{array}$ & $5 \%$ \\
\hline $\begin{array}{l}\text { Immunoblastic } \\
\text { lymphomas }\end{array}$ & $\begin{array}{l}1 \\
2 \\
3 \\
4 \\
5\end{array}$ & $\begin{array}{l}\text { few } \\
\text { few } \\
5 \% \\
5 \% \\
30-40 \%\end{array}$ & $\begin{array}{l}\text { few } \\
\text { few } \\
5 \% \\
5 \% \\
30-40 \%\end{array}$ & $\begin{array}{l}\text { few } \\
\text { few } \\
\text { few } \\
\text { few } \\
20-25 \%\end{array}$ & $\begin{array}{l}1: 1 \\
1-2: 1 \\
2: 1 \\
2: 1 \\
1-2: 1\end{array}$ & $\begin{array}{l}10-20 \% \\
10-15 \% \\
\text { few } \\
5-10 \% \\
20 \%\end{array}$ & $\begin{array}{l}\text { few } \\
10 \% \\
10 \% \\
10-15 \% \\
5 \%\end{array}$ & few \\
\hline
\end{tabular}

Percentage estimated semiquantitatively from total number of cells in a tumour.

DEMONSTRATION OF ANTIGENS ON FROZEN TISSUE SECTIONS

Frozen tissue sections were cut at $6 \mu \mathrm{m}$. The sections were dried, fixed in acetone (10min) dried again and left in the freezer for at least $30 \mathrm{~min}$. They were then dried and fixed again (acetone, $10 \mathrm{~min}$ ) and the immunoperoxidase procedure was started. An indirect technique was used. The monoclonal and heterologous antisera used and their specificity are given in Table 1 . The anti-C3b receptof serum was prepared by immunising rabbits with highly purified human erythrocyte $\mathrm{C} 3 \mathrm{~b}$ receptors (anti-CR 1 ). It was purified as described by Fearon. ${ }^{33}$ The antiserum $\frac{7}{0}$ recognises glycoprotein with a molecular weight of 213000 . In this study the IgG fraction of the antiserum was used. As a second step for the monoclonal $\mathbb{Q}$ mouse-antibodies a rabbit-antimouse IgG tagged with 
horseradish peroxidase (Dakopatts, Denmark) was used. The heterologous rabbit antisera (kappa, lambda, alpha, gamma, mu, anti $\mathrm{C} 3 \mathrm{~b}$ receptor and common acute lymphoblastic leukaemia antigen (CALLA)) were followed by the goat-antirabbit IgG, prepared in our laboratory. All antisera were first tested on normal tissues - for example, lymph node, spleen, tonsil, thymus, and for NA 1/34 and OKT6, on skin. Controls were performed by replacing the monoclonal antibody with phosphatebuffered saline.

\section{Results}

The results are summarised in Tables 2 (a) and (b). The histiocytic sarcomas showed a typical staining pattern. The tumour cells stained positive with TAl, antihuman monocyte 1 (Fig. 1), weakly with OKMl and Macl and also with HLA-DR and anti-C3b receptor. A varying percentage stained positive with NAl/34. TAl and antihuman monocyte 1 were most effective, whereas OKMl and Macl staining of histiocytes was weak; OKM1 staining of granulocytes was much stronger. No tumour cells stained positive with Leu1, Leu2a, Leu3a, OKT3, OKT4, OKT6, OKT8, BA2, VIM-D5, anti-elastase, CALLA or for kappa, lambda, alpha, mu, gamma or on

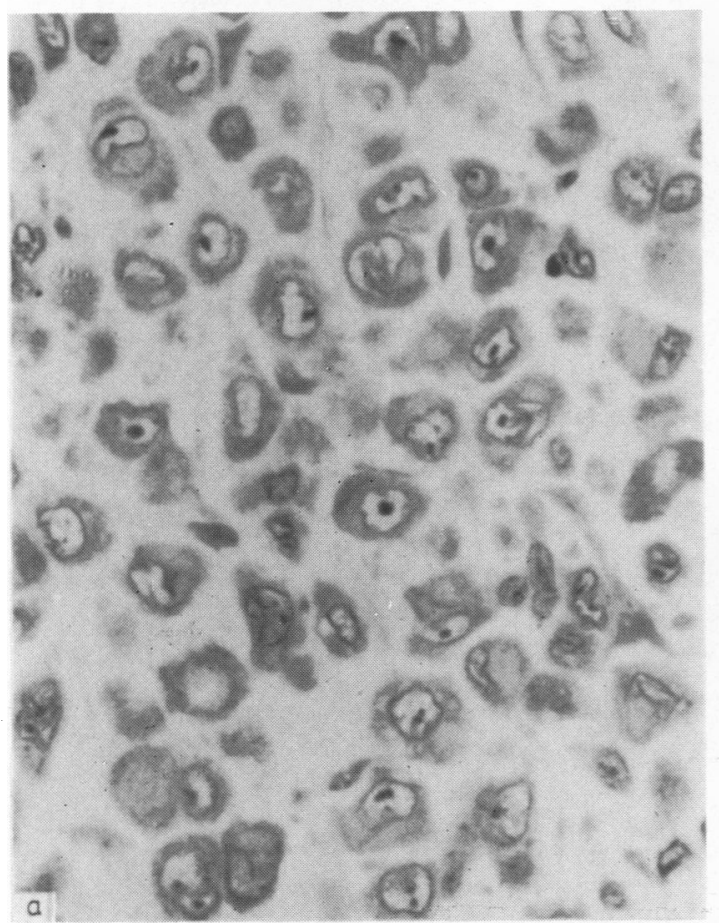

cell membranes. The positive staining of the tumour cells was always intracytoplasmic, only HLA-DR being discernible on membranes occasionally. Admixture was low in three cases (cases 2, 3,4) and somewhat higher in 2 (cases 1,5 ). T lymphocytes tended to predominate and approximately equal numbers on Leu3a (helper/inducer T phenotype) and Leu2a (suppressor/cytotoxic T phenotype) were found. B lymphocytes were relatively scarce except in case 1 . In the case of malignant histiocytosis the staining pattern of the tumour cells was identical to that of the histiocytic sarcomas.

The centroblastic lymphomas showed a positive staining with the anti-C3b receptor (Fig. 2) and HLA-DR antisera. With the latter, however, only a quarter of the tumour cells stained positive in two cases (cases 4,5 ) and staining was weak in two other cases (cases 1,2). With BA1 only one case showed a few positive tumour cells (case 4) while with BA2 half the tumour cells were positive in case 5 and a few were positive in cases 1 and 2 . Again the number of admixed cells was low (Table 2(b)) and as with the histiocytic sarcoma equal numbers of Leu3a and Leu2a positive cells were found. Varying numbers of macrophages were present, up to $20 \%$ in one case (case 5).

Although in B-immunoblastic lymphomas a staining
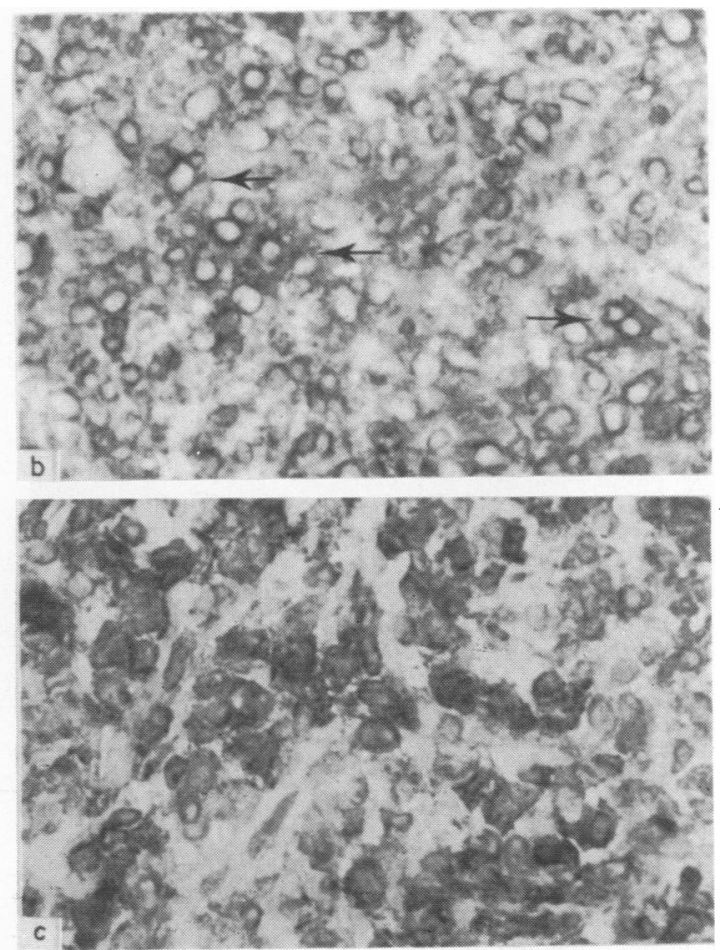

Fig. 1 Histiocytic sarcoma. (a) Giemsa-stained, methyl-methacrylate-embedded section. Cells have abundant cytoplasm and pronounced nuclear irregularity. $\times 350(b)$ TAl staining. Many cells show intracytoplasmic staining (arrows). $\times 140(c)$ Staining with anti-human monocyte 1 . Most cells stain positive. $\times 140$ 

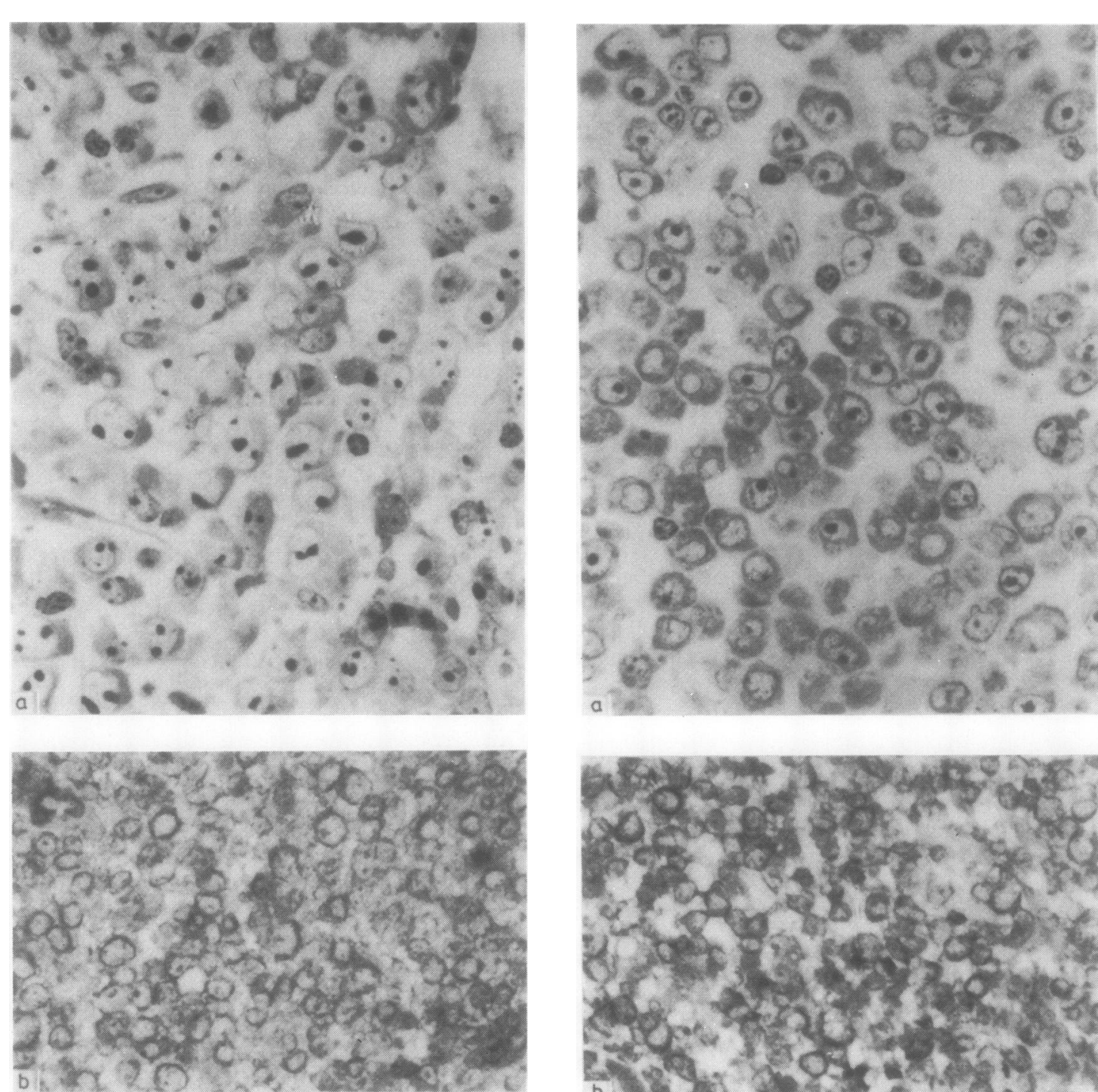

Fig. 2 Centroblastic lymphoma. (a) Giemsa-stained methylmethacrylate-embedded section. Note the multiple, mostly marginal nucleoli. $\times 350$ (b) Staining with the anti $C 3 b$ receptor serum. Tumour cells are positive. $\times 140$

Fig. 3 B-immunoblastic lymphoma. (a) Giemsa-stained methyl-methacrylate-embedded section. Tumour cells have moderate cytoplasm. Most nuclei have a conspicuous central nucleolus. $\times 350$ (b) HLA-DR staining. Tumour cells are positive the antiserum stains the membranes. $\times 140$ (c) BA-l staining. Most cells are positive staining occasionally is intense. $\times 140$
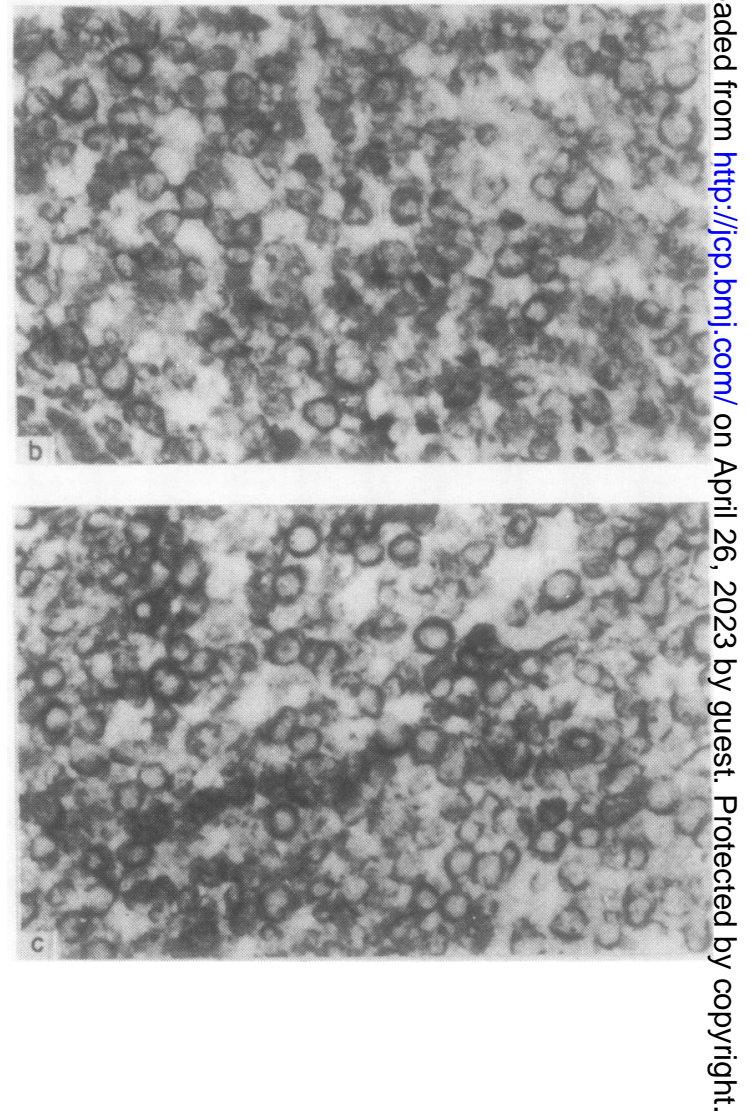
pattern that resembled that of the centroblastic lymphomas was found, differences were noted. The staining for HLA-DR was strong to very strong in all but one case (case 4), while anti-C3b receptor staining was much weaker than in centroblastic lymphomas, or was absent. BA1 staining was observed in four or five cases varying from a few positive tumour cells (case 3 only) to a high proportion of tumour cell positive in cases 1 and 5 . In two cases BA2 staining was found (cases 3 and 4). The staining pattern is illustrated in Fig. 3.

With VIM-D5 and anti-elastase in some cases granulocytes were identified and BA2 was found to stain vessels and fibrocytes.

\section{Discussion}

Even though the number of cases investigated was small, the results of this study confirm the usefulness of monoclonal and heterologous antibodies in distinguishing effectively histiocytic sarcoma from B-immunoblastic and centroblastic lymphoma. A gradual difference was noted between these two B-lymphoid tumours, albeit a slight one. The neoplastic cells of the histiocytic sarcomas stained with the antibodies known to be reactive with antigens on monocytes/macrophages: antihuman monocyte 1, OKM1 and Macl (rather weak) TA1, HLA-DR and anti-C3b receptor. This and the absence of staining with VIM-D5 and anti-elastase makes a myeloid origin of these tumours very unlikely. Staining with NA1/34 was also observed. This antiserum proved reactive with thymocytes, Langerhans cells and interdigitating reticulum cells, like OKT6, as was reported by Murphy et al. ${ }^{29}$ The latter two types of cells are thought to be monocytederived, ${ }^{34}$ which may explain the staining of histiocytes. OKT6, however, was negative throughout. The one case of malignant histiocytosis showed a staining pattern identical to the five histiocytic sarcomas.

Between B-immunoblastic and centroblastic lymphomas a gradual difference was noted in the staining for HLA-DR, anti-C3b receptor and BA1. The tumour cells of B-immunoblastic lymphoma stained weakly or not at all with anti-C3b receptor but strongly with HLA-DR (though one case was almost completely negative) and BAl staining for varying numbers of cells was seen. In centroblastic lymphoma this pattern was reversed: positive staining with anti-C $3 b$ receptor, weaker staining with HLA-DR and virtual absence of the BA1 antigen. BA2 proved to be present on three cases of centroblastic and two cases of B-immunoblastic lymphoma. This monoclonal antibody is raised against B-cells in a very early developmental stage and its appearance so much later in the development of the B lymphocyte is strange. Positive staining of centroblastic lymphomas with another "early" antigen-that is CALLA, has been reported (W Knapp, personal communication 1982). We were not able to demonstrate CALLA on our cases, but these findings are a reminder that caution is warranted in regarding CALLA and $\mathrm{BA} 2$ as maturation antigens.

It must be stressed that the difference between B-immunoblastic and centroblastic lymphomas is a gradual one and not absolute. It has already been shown ${ }^{3536}$ that centroblastic lymphoma can be polymorphic in cell types, with frequent admixture of immunoblasts. Morphometrically the same observation has been demonstrated. ${ }^{14}$ Another observation is the immunological heterogeneity of both centroblastic and immunoblastic lymphomas, best illustrated by the results for BA1 and BA2 staining. Recent studies on isolated non-Hodgkin's lymphoma cells by Godal $e t a l^{37}$ have shown similar findings for other lymphomas.

The reactive cells present in the tumour were also studied. Most of the large-cell lymphomas showed little admixture with reactive cells. Cases 1 and 5 of histiocytic sarcomas, case 2 of centroblastic and case 5 of B-immunoblastic lymphomas showed more substantial admixture. Whatever the number of admixed cells the pattern did not differ much; approximately equal numbers of $T$ and $B$ lymphocytes were found, with a tendency of predominance of the $T$ cells. The distribution of the different $T$ cell subsets showed a shift in the ration of helper/inducer (Leu3a/OKT4+) and suppressor/ cytotoxic (Leu2a/OKT8+) cells. This ratio normally is $2-3: 1,{ }^{38}$ but here varied between $1: 1$ and $2: 1$. This appeared to be slightly more pronounced in histiocytic sarcoma and centroblastic lymphoma but as the number of $T$ lymphocytes was generally low, these findings must be interpreted with caution. Although no double-labelling experiments were done, studies on adjacent sections did not suggest that large numbers of cells positive for both Leu2a and Leu3a were present. Similarly, cells staining for both HLA-DR and Leu 1 , the phenotype of activated T cells, were not present in large numbers though it was difficult to compare these two antigens in most cases of B-immunoblastic lymphomas where HLA-DR staining of tumour cells was strong. In both B-lymphoid tumours a fairly large number of macrophages/histiocytes was observed (up to $20 \%$ in one case).

In conclusion the monoclonal antibodies TA1, antihuman monocyte 1, OKM1, Macl and NA1/34 can be used to differentiate histiocytic sarcoma from the other large-cell lymphomas. The differentiation between Bimmunoblastic and centroblastic lymphoma remains difficult, because the diagnostic classes appear to be morphologically and immunologically heterogeneous. The presence of strong HLA-DR staining, with weak or absent anti-C3b receptor staining and the presence or absence of BAl antigen may be helpful. The results underline the assumption that the diagnosis of nonHodgkin's lymphomas should not be based on studies with monoclonal and/or heterologous antibodies alone, but requires other techniques as well, such as cytochemistry, electron microscopy and morphometry. 
The authors wish to thank Drs $\mathbf{J}$ Kersey and $\mathbf{J}$ Jansen for the BA1, BA2 and TA1 antisera, and Dr W Knapp for the VIM-D5 antiserum, and Mrs R J J R Scholte for typing the manuscript.

\section{References}

' Warnke R, Miller R, Grogan R, Pederson M. Dilley J. Levy R. Immunological phenotype in 30 patients with diffuse large-cell lymphoma. N Engl J Med 1980:303:293-300.

2 Bosman FT. Kreuning J, van der Wal AM. Kuiper G, Lindeman J. The influence of fixation on immunoperoxidase staining of plasma cells in paraffin sections of intestinal biopsy specimens. I Histochem Cytochem 1977:53:57-62.

'Te Velde J. Burkhardt R. Kleiverda K. Leenheers-Binnendijk L. Sommerfield W. Methyl-methacrylate embedding medium in histopathology. Histopathology 1977:1:319-30.

${ }^{4}$ McDowell EM. Trump BF. Histological fixative suitable for diagnostic light and electron microscopy. Arch Pathol Lab Med 1976:100:405.

s van der Valk P. Te Velde J. Jansen J. et al. Malignant lymphoma of true histiocytic origin: histiocytic sarcoma. A morphological. ultrastructural. immunological. cytochemical and clinical study of 10 cases. Virchows Arch [Pathol Anat] 1981:391:249-65.

'Kramps JA. Van der Valk P. Mooren HWD. Meijer CJLM. Anti-elastase: a rabbit-antihuman antibody recognising polymorphonuclear elastase (manuscript submitted).

Meijer CJLM. Lindeman J. A modified method for tissue localisation of cells bearing a complement receptor. J Immunol Methods 1975:9:5965 .

${ }^{x}$ Meijer CJLM. Van de Putte LBA. Eulderink F. Kleinjan R. Lafeber G. Bots GThAM. Characteristics of mononuclear cell populations in chronically inflamed svnovial membranes. J Pathol 1977:121:1-8.

"Barka T. Anderson PJ. Histochemistry: theory. practice and bibliography. 2nd ed. New York: Hoeber Medical Division. Harper-Row. 1965

"' Gomori G. The study of en/ymes in tissue sections. Am J Clin Pathol 1946:16:347-52

"Wachstein M. Meisel E. Histochemistry of hepatic phosphatases at a physiological $\mathrm{pH}$ with a special reference to the demonstration of bile canaliculi. Am J Clin Pathol 1957:27:13-23.

12 Gerard-Marchant R. Hamlin I. Lennert K. Rilke F. Stansfeld AG, van Unnik JAM. Classification of non-Hodgkin's lymphomas. Lancet 1974:ii:406.

1' Lennert K. Stein H. Kaiserling E. Cytological and functional criteria for the classification of malignant lymphomata. $\mathrm{Br} J$ Cancer 1975:31:suppl II 29-4.3

it van der Valk P. Hermans J. Brand R. Cornelisse CJ. Spaander PJ. Meijer CJLM. Morphometric characterisation of diffuse large-cell (histiocytic) lymphomas. Am J Pathol 1982:107:327 -35.

${ }^{15}$ Byrne GE. Rappaport H. Malignant histiocytosis. From Gamn monograph on cancer research 15. 1973.

${ }^{16}$ Wang CY. Good RA. Ammirati P. Dymbort G. Evans RL. Identification of p69.71 complex expressed on human T-cells sharing determinants with B type chronic lymphocytic leukemic cells. J Exp Med 1980:151:1539-44.

${ }^{17}$ Ledbetter JA. Evans RL. Lipinski M. Rundles C. Good RA. Herzenberg LA. Evolution conservation of surface molecules that distinguish T-lymphocyle helper/inducer and cytotoxic/suppressor subpopulations in mouse and man. J Exp Med 1981:153:310-23.

${ }^{1 *}$ Evans RL. Wall SW. Platsoucas CO. el al. Thymus-dependent membrane antigens in man: inhibition of cell-mediated lympholysis by monoclonal antibodies to TH2 antigen. Proc Natl Acad Sci USA 1981:78:544-8

${ }^{19}$ Reinherz EL. Kung PC. Goldstein G. Schlossman SF. Further characterisation of the human inducer T-cell subset defined by a monoclonal antibody. J Immumol 1979:123:2894 6.
20 Reinherz EL. Kung PC, Goldstein G. Schlossman SF. A monoclonal antibody reactive with the human cytotoxic/suppressor T-cell subset. previously defined by a heteroantiserum termed TH-2. J Immunol 1980:124:1301-7.

${ }^{21}$ LeBien TW. Kersey H. A monoclonal antibody (TAl) reactive withro human T-lymphocytes and monocytes. J Immunol 1980:125:220814.

22 Abramson CS. Kersey JH, LeBien TW. A monoclonal antibody (BA1) $\frac{\bar{\sigma}}{\partial}$ reactive with cells of human B-lymphocyte lineage. J Immunol 1981:126:83-8

23 Kersey JH. LeBien TW. Abramson CS. Newman R. Sutherland R, ש Greaves M. p24: a human leukemia associated and lymphopoietic $\vec{O}$ progenitor cell surface structure identified with monoclonal antibody. J Exp Med 1981:153:726-31.

${ }^{24}$ Warnke R, Levy R. Detection of T- and B-cell antigens with hybridoma monoclonal antibodies: a biotin-avidin-horseradish peroxidase method. J Histochem Cvtochem 1980:28:771-6.

25 Breard J, Reinherz EL. Kung PC. Goldstein G, Schlossman SF. A w monoclonal antibody reactive with human peripheral blood monocytes. J Immunol 1980:124:1943-8.

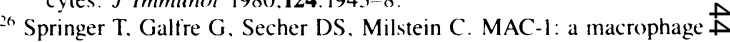
differentiation antigen identified by monoclonal antibody. Eur $J$ 음 Imınunol 1979:9:301-6.

${ }^{27}$ Ugolini V. Nunez G. Smith GR. Stastny P. Capra JD. Initial characterisation of monoclonal antibodies against human monocytes. की Proc Nall Acad Sci USA 1980:77:6764-8.

${ }^{2 x}$ Reinher 2 EL. Kung PC. Goldstein G. Levey RH. Schlossman SF. ف Discrete stages of human intrathymic differentiation: analysis of normal thymocytes and leukemic lymphoblasts of T-lineage. Proi $\overrightarrow{c 0}$ Natl Acad Sci USA 1980:77:1588-92.

"Murphy GF. Bhan AR. Sato S. Mihm jr MC. Harrist TJ. A new. immunologic marker for human Langerhans cells. $N$ Engl J Med 1981:304:791-2.

3) McMichael AJ. Pilch JR. Galfre G. Mason DY. Fabre JW. Milstein C. A human thymocyte antigen defined by hybrid myeloma monoclonal $\bar{O}$ antibody. Eur J Immunol 1979:9:205-10.

"Brown G. Capellaro D. Greaves MF. Leukemia associated antigens in $\mathbb{D}$ man. J Natl Cancer Inst 1975;55:1281-9.

3 Knapp W. Maydic O. Rumpold Het al. Myeloid differentiation antigens $\overline{\bar{O}}$ as defined by monoclonal antibodies. In: Knapp W. ed. Leukemia 3 Markers Proceedings of the Leukemia Marker Conference (Vienna 1981) New York: Academic Press. 1981:201-23.

Fearon DT. Regulation of the amplification C 3 convertase of human complement by an inhibitory protein isolated from human erythro- $\bar{O}$ cyte membrane. Proc Nat Acad Sci USA 1979:76:5867-71.

${ }^{4}$ Hoefsmit EChM. Mononuclear phagocytes, reticulum cells and $\frac{\sigma}{3}$ dendritic cells in lymphoid tissues. In van Furth R. ed. Monomuclear. phagocvtes in immunology: infection, and patholog: Oxford: 응 Blackwell Scientific Publications. 1975.

${ }^{35}$ Lukes RJ. Collins RD. New approaches to the classifications of the lymphomata. Br J Cancer 1975:31 suppl II:1-28.

3o Lennert K. Malignant lymphomas, other than Hodgkin's disease. In:D Handbuch der speziellen pathologischen Anatomie und Histologic'을 Vol I/3/B Berlin: Springer-Verlag. 1978.

${ }^{37}$ Godal T. Lindmo T, Morton PF. et al. Immunological subsets in human $\mathrm{N}$ B-cell lymphomas. Scand J Immunol 1981:14:481-92.

${ }^{3 *}$ Willemze R, de Graaf-Reitsma CB. Cnossen J, van Vloten WA. Meijero CJLM. Characterisation of $T$ cell subpopulations in skin and $\mathbb{W}$ peripheral blood of patients with cutaneous $\mathrm{T}$ cell lymphoma and benign inflammatory dermatoses. I Invest Dermatol (in press).

:Daha MR. Kole D)J. Van Es L.A. Regulation of the ( 3 nephritic factore stabilized $\left(3, \mathrm{C} 5\right.$ convertase of complement by purified human $\frac{C}{D}$ erythroyte (3b receptor. Clin Exp. Immmonol 1982:50:209 14.

Requests for reprints to: Dr P van der Valk. Department of $\frac{T}{\bar{O}}$ Pathology. University Medical Centre. PO Box 9603. 230() RC Leiden. The Netherlands. 